\title{
Accounting
}

\section{The impact of capital structure on the performance of construction companies: A study from Vietnam stock exchanges}

\author{
Thi Thanh Thuy Vu ${ }^{a^{*}}$, Thi Tu Oanh Le $e^{a}$ and Thi Huyen Trang Nguyen ${ }^{a}$
}

\begin{tabular}{l}
${ }^{a}$ University of Labour and Social Affa \\
\hline C H R O N I C L E \\
\hline Article history: \\
Received September 22019 \\
Received in revised format \\
September 22019 \\
Accepted October 152019 \\
Available online \\
October 222019 \\
\hline Keywords: \\
Capital structure \\
Construction companies \\
Performance \\
Vietnam Stock Exchanges \\
\hline
\end{tabular}

\section{Introduction}

Capital structure has been a popular research topic conducted in various industries and countries around the world. As a developing country, capital structure and firm performance are topics of high interest among scholars in Vietnam, especially those conducted for construction firms. According to the Industrial Statistics Department of Vietnam, construction firms make up to $14.8 \%$ of the total number of firms in Vietnam, creating $16 \%$ of total jobs in the Vietnamese labor market. However, return on assets (ROA) and return on equities (ROE) of these firms are quite low. Analysis from Lan (2013) shows that the level of financial leverage of these firms is quite high, which is an alert signal for listed construction firms in particular and for the whole construction industry in general. The question is that "What can be done in order to push up the firm performance for construction firms listed on the Vietnam Stock Exchange?" There is not any organization in charge of credit rating and firm performance assessment to provide consulting services about this situation for firms in Vietnam. In order to pursue the purpose of business financial management and to maximize the asset value for the owner, it is necessary for the construction companies to form the optimal capital structure. The capital structure has a large impact on firm performance. In fact, a company can pursue a debt-heavy capital structure with a low weighted average cost of capital. However, this can result in negative effects on a firm's financial health. Therefore, it is important for each firm to determine the effects of capital structure on its performance. Therefore, there is a research gap since there has not any research about the impact of capital structure on the performance of construction firms listed on the Stock Exchange in Vietnam.

In order to analyze the situation of construction firms' performance listed on the Stock Exchange in Vietnam, there are a number

* Corresponding author

E-mail address: thuyhuong7879@gmail.com (T.T.T. Vu) 
of factors taken into consideration in this research. The first factor is the capital size. The construction companies listed companies are quite different in their sizes of capital, and can be sorted into three groups: less than 1,000 billion Vietnam dong (VND), 1,000 billion to 5,000 billion VND, and more than 5,000 billion VND. In 2014, there were 40 companies with capital less than 1,000 billion VND, 14 companies with capital from 1,000 billion to 5,000 billion VND, 5 companies with capital more than 5,000 billion VND, which accounted for $67.8 \%, 23.7 \%$ and $8.5 \%$ of total sample companies respectively. In 2015 , there was a decrease in the number of companies with capital less than 1000 billion VND to 35 companies ( $38 \%$ of the total sample) while the number of those with capital more than 1000 billion VND increased gradually. In 2016, due to the fluctuation of the property market, some of those companies reduced in size, and the number of companies with capital more than 1000 billion VND was not changed compared with 2014. The second factor is equity to total capital. This factor represents the financial autonomy of these construction companies. In 2014, the average equity-capital ratio of companies with capital less than 1,000 billion VND was $26.96 \%$, while the number for companies with capital from 1,000 billion to 5,000 billion VND was 29.51 and for those with capital over 5,000 billion VND it was much lower (10.8\%). However, in 2016, this situation changed with 39\% for construction companies in the largest size group. This result shows that firms' financial autonomy was improved while the economy was on the way of recovery from the economic crisis. The changes in average equity-capital ratio through research time frame resulted in changes in debt-to-total capital ratio. It is worth noting that for several companies, there was 16.94 VND value of debt for every 1 VND value of capital, which was the highest level of debt in a three-year time frame. The reason for that is the companies were operating at deep loss, resulting in their equity less than 0 . The third factor is associated with the long-term debt to total capital. This factor represents the level of the construction companies' capital dependence from outside resources such as loans from banks, issues of bonds or stocks to finance its business. etc. For Vietnamese companies in general and construction companies in particular, long-term capitals have mostly come from bank loans and the number of companies financed by issuing bonds makes up a smaller proportion. Descriptive statistics show that the group of companies with larger total of assets also has a higher level of total long-term debt/total capital. Specifically, the level of long-term debt/total asset for the companies with capital less than 5,000 billion VND was 10.14\%, 9.6\% and 10.77\% in 2014, 2015 and 2016 respectively. Meanwhile, this number for companies with capital over 5000 billion VND was quite high at 20.36\%, 21.65\% and $18.54 \%$ in 2014, 2015 and 2016 respectively, which is corresponding to specific operating characteristics of construction companies. The fourth factor - the fixed assets to total assets. The fixed assets to total assets represent assets structures and operational capability of the companies. In 2014, the companies with smaller total capital tended to focus on fixed assets investments, which was reasonable since they had yet to build up strong brand names and prestige, hence investing equipment is a better way to push up their operational capability. However, in 2015 and 2016, companies with a high level of fixed assets to total assets concentrated in group 1000 billion to 5000 billion VND value of capital.

\section{Literature review}

Capital structure has been a popular topic among the financial research area. There have been numerous studies conducted to examine the relationship between capital structure and firm performance (Chaganti \& Damanpour, 1991; Margaritis \& Psillaki, 2010; Tudose, 2012). Various studies have been conducted specifically for developing countries such as Malaysia, Jordan, India, Bangladesh, and Nigeria (David \& Olorunfemi, 2010; Dawar, 2014; Hasan et al., 2014; Salim \& Yadav, 2012; Zeitun \& Tian, 2007). Another research worth mentioning is one accomplished by $\mathrm{Xu}$ et al. (2005). They found that there was a positive correlation between ROE and debt ratio. Margaritis and Psillaki (2010) showed the relationship between capital structure and firm performance. By using the econometric model, Su and Vo (2010) found a reverse relationship between debt ratio and company size, estimated as follows:

$$
R O E=b_{0}+b_{1} \times G P+b_{2} \times L I-b_{3} \times D R-b_{4} \times F S+e,
$$

where, GP is the growth capability; $L I$ is the liquidity, calculated based on cash and cash equivalent/book valueof total assets; $D R$ is the debt ratio and $F S$ is the company size. Salim and Yadav (2012) investigated the relationship between the capital structure and company performance in Malaysia based on two following models:

$$
\begin{aligned}
& R O E(\text { performance })=\beta_{0}+\beta_{1} L T D+\beta_{2} \text { Size }+\beta_{3} \text { Growth }+\beta_{4} T D+\beta_{5} S T D+\varepsilon, \\
& R O A(\text { performance })=\beta_{0}+\beta_{1} L T D+\beta_{2} \text { Size }+\beta_{3} \text { Growth }+\beta_{4} T D+\beta_{5} S T D+\varepsilon,
\end{aligned}
$$

where, $L T D$ is the long term debt to total assets, Size is the logarithm of total assets, Growth is changes in total assets, STD is the short term debt to total assets, and $\varepsilon$ is the error term. Tu (2006) assessed the capital structure of a sample of 375 state-owned companies. In this study, the econometrics model, finance forecasting, prospect analysis and trade-off theory were used to form the capital structure for Civil Engineering Construction Corporation No 1 - JSC. This research used a one-year data range for financial forecasting, which cannot perform capital structure assessment for a long-term period. Besides, the cost of capital estimated based on book value does not represent the market value. The author analyzed the issues related to the optimal capital structure of construction companies. Similarly, Tu (2006) used 45 non-financial companies listed on the Hochiminh Stock 
Exchange to investigate the factors affecting the capital structure of listed companies in Vietnam. The theory showed different ways of effects and this research has achieved a positive empirical result, however, there is a lack of unification of scope and methods for estimating regression variables. Son (2008) analyzed the effects of capital structure on profitability by using the following model:

\section{PROF $=f($ Leverage, Growth, Size, Tang, State $)$}

where $P R O F$ measures the effectiveness of ROE and ROA, Leverage is total debt/total assets, total long-term debt/total assets and total short-term debt/total assets; Growth is the business growth rate; Size is the size of the company; State is the stateowned capital. This research indicated the relationship between short-term debt/total capital, total debt/total capital and stateowned capital and ROE and ROA, but yet to assess the relationship between long-term debt, company size, growth rate with ROE and ROA. There are a number of studies focused on capital structure impacts, however, there is a lack of research on impacts of capital structure on firm performance for construction firms listed on Stock Exchange in Vietnam.

\section{Conceptual framework and methods}

\subsection{Conceptual framework}

Based on the research done by Salim and Yadav (2012), this research is conducted for listed construction companies in Vietnam since Vietnam and Malaysia both have many similar features in the process of economic development.

Data for this research is taken from the public on companies' websites in order to calculate ratios for analysis. All data to form financial ratios of this research is taken from annual audited financial statements of listed construction companies in three years from 2014-2016, include 59 construction companies (177 observations).

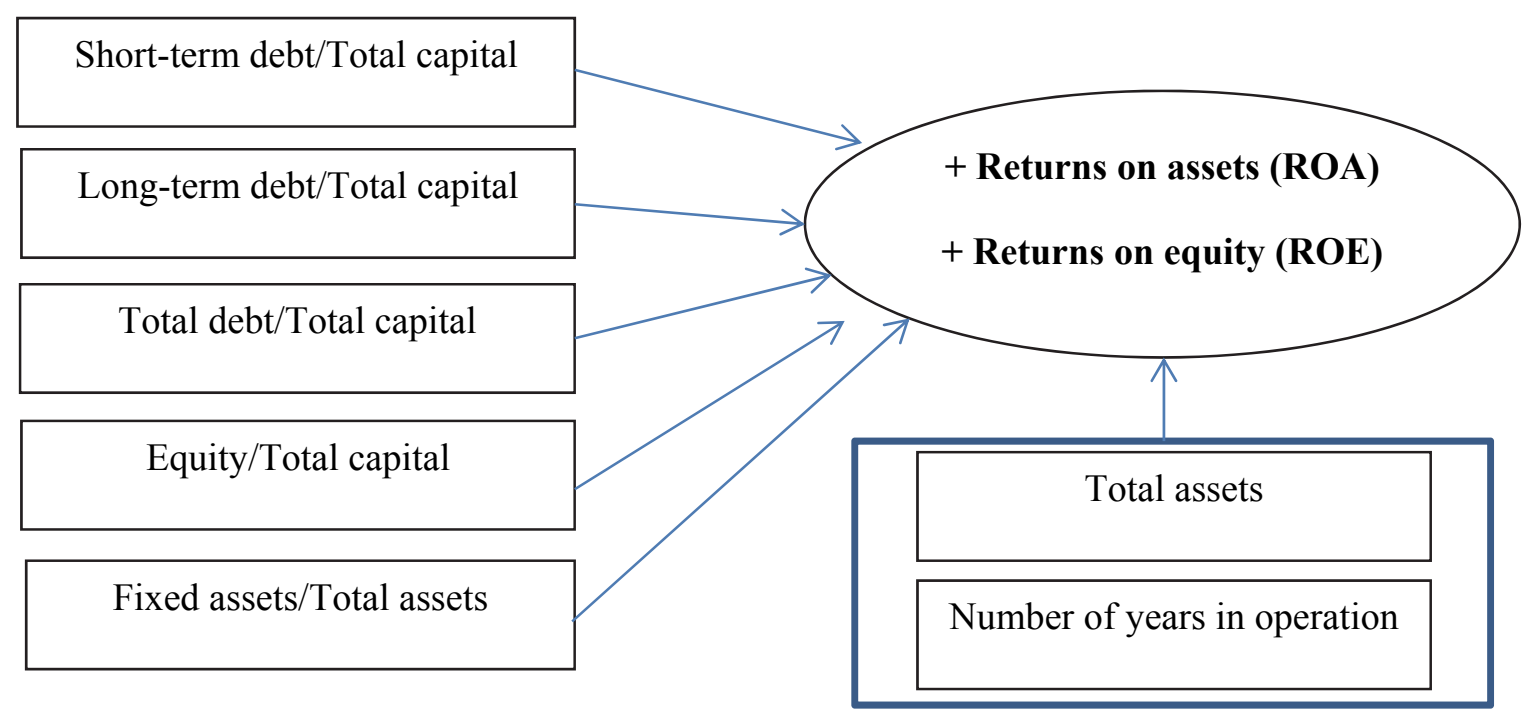

Fig. 1. Conceptual framework

These data are downloaded, extracted to yearly data under excel form, assembled into one file, then they are transferred to SPSS format. Based on that data, ratios of capital structure including short-term debt/total assets, long-term debt/total assets, total debt/total assets, and equity/total assets are calculated. Ratios reflecting firm performance (ROA and ROE) are also estimated. Since the research data is taken from the annual audited financial statements of listed construction companies, it meets the requirements for reliability and accuracy for the research. The data have been taken from annual audited financial statements of listed construction companies and they meet the requirements for reliability and accuracy for the research. Besides, information about the business plan, the direction of growth, competitive advantages of each company can be acquired from the websites of sample companies. This information can be used to explain the changes in the performance of these companies. A conceptual framework is displayed in Fig. 1. The analysis for this model is conducted under two steps. First, the descriptive statistics is used for sample of 59 construction companies listed on Stock Exchange in Vietnam to depict the operation of these companies, including: long-term debt, short-term debt, the proportion of fixed assets, short-term debt/total capital, long-term debt/total capital, total debt/total capital, fixed assets/total assets, total assets, and the number of years in operation. Second, the regression correlation analysis is conducted in order to investigate the relationship between independent variables and dependent variables. If there is a relationship between these two kinds of variables, this research also attempts to figure out whether they are strong or lose, positive correlation or negative correlation in order to determine the most effective model to analyze and forecast the relationship between capital structures and firm performance.

\subsection{Research methods}


To assess the relationship between capital structure and performance of listed construction companies in Vietnam, authors used correlation analysis. Apart from descriptive statistics presented in the previous part, economic models are employed to analyze the impact of capital structure and control variables on firm performance of listed construction companies in the period 20142016 and to forecast for the future. Based on the model represented above, ROA and ROE are used as dependent variables to represent the performance of construction companies in this research. In similar studies, variables for firm performance analysis are selected based on the particular industry. This research applied a linear regression model, similar to other studies mentioned in the literature review. Therefore, in this research, variables reflecting capital structure are selected in order to be suitable for Vietnam. Variables for this experiment are described as below:

- Dependent variables: ROE and ROA - measure the firm performance of the companies, in which ROA is the returns on assets calculated by net income/total assets; ROE is the returns on equity, calculated by net income/equity.

- Independent variables:

- LERa: Financial leverage, calculated by total debt/total capital, which reflexes the capital structure of companies.,

- LERb: long-term debt/total capital. LERb is the variable represents the capital structure,

○ LERc: Total debt/equity,

- TANG: Asset structure calculated by fixed assets/total assets,

- SIZE: company size calculated by the logarithm of total assets of the company,

○ $N U$ : Number of years in operation.

(Size and $\mathrm{Nu}$ are control variables).

In order to analyze the relationship between firm performance and capital structure, ordinary least squares (OLS) was applied to estimate the parameters. Control variables were also used in this experiment; therefore, the estimation process was executed in two stages. In stage 1, two control variables - the size of the company and number of years in operation - are used to examine the changes of ROA and ROE. In stage 2, independent variables are added to examine the explanation capability of these variables for the changes of ROA and ROE. Linear regression model used to examine the impact of capital structure on firm performance is determined as follows:

$$
\begin{aligned}
& R O A=f(L E R a, L E R b, L E R c, \text { Size }, N U) \\
& R O E=f(L E R a, L E R b, L E R c, \text { Size }, N U)
\end{aligned}
$$

\section{Results and discussions}

The capital structure situation of companies in the sample is described through following factors: (1) the situation of capital size, (2) the situation of equity to total capital, (3) the situation of long-term debt to total capital, (4) the situation of total fixed assets to total assets, (5) the situation of firm performance of listed construction companies, (6) analysis of the relationship between the capital structure and the performance of listed construction companies. The firm performance assessment would be performed before assessing the relationship between capital structure and firm performance. For this purpose, ROA and ROE are used to assess the firm performance of listed companies in Vietnam in general and listed construction companies in Vietnam in particular.

\subsection{Returns on assets (ROA)}

The ROA of sample companies is present in Table 1.

\section{Table 1}

\begin{tabular}{|c|c|c|c|c|c|c|}
\hline Year & Total assets & & $\mathbf{N}$ & Minimum & Maximum & Mean \\
\hline \multirow{3}{*}{2014} & Less than 1000 billion VND & $\mathrm{ROA}$ & 39 & -.4632 & 24.4263 & .618759 \\
\hline & 1000 billion - 5000 billion VND & $\mathrm{ROA}$ & 14 & -.0229 & .0673 & .020219 \\
\hline & Over 5000 billion VND & ROA & 5 & -.1875 & .0415 & -.021435 \\
\hline \multirow{3}{*}{2015} & Less than 1000 billion VND & ROA & 32 & -.1779 & .1053 & -.006234 \\
\hline & 1000 billion - 5000 billion VND & ROA & 17 & -.0075 & .0698 & .021597 \\
\hline & Over 5000 billion VND & ROA & 5 & -.1815 & .0394 & -.021357 \\
\hline \multirow{3}{*}{2016} & Less than 1000 billion VND & $\mathrm{ROA}$ & 32 & -.6208 & .1138 & -.013868 \\
\hline & 1000 billion - 5000 billion VND & ROA & 15 & -.0318 & .0682 & .017935 \\
\hline & Over 5000 billion VND & ROA & 4 & .0071 & .0497 & .032561 \\
\hline
\end{tabular}

ROA of listed construction companies in Vietnam

Source: Compiled by the authors based on research results

In 2014, ROA fluctuated between $-46.32 \%$ and $2442 \%$. Profitability amplitude of assets of group 1,000 billion companies was larger, with average ROA was $61.87 \%$. This number in 2015 is just $-0.6 \%$, ROA is fluctuating between $-17 \%$ and $10.53 \%$. In 2016, the highest ROA is just 11.53\%. Average ROA was increased for a group of larger size of assets in 2014-2015. One reason 
for the decreasing in average ROA was the tighter supervision policy for operation schedule which helps to ensure the right for house buyers and other stakeholders.

\subsection{Returns on equity (ROE)}

With the change in the opinion about the final financial goal to maximize the owner's value, ROE became the important ratio reflecting firm performance. Similar to the ROA analysis, Table 2 represents the data for ROE analysis.

Table 2

ROE of listed construction companies

\begin{tabular}{|c|c|c|c|c|c|c|}
\hline Year & Total assets & & $\mathbf{N}$ & Minimum & Maximum & Mean \\
\hline \multirow{3}{*}{2014} & Less than 1000 billion VND & ROE & 38 & -1.8176 & 61.3362 & 1.727427 \\
\hline & 1000 billion - 5000 billion VND & ROE & 14 & -1.1052 & .1390 & -.009855 \\
\hline & Over 5000 billion VND & ROE & 5 & .0093 & .7425 & .219202 \\
\hline \multirow{3}{*}{2015} & Less than 1000 billion VND & ROE & 32 & -20.2411 & 65.0905 & 1.574387 \\
\hline & 1000 billion - 5000 billion VND & ROE & 17 & -.0290 & .2280 & .074444 \\
\hline & Over 5000 billion VND & ROE & 5 & .0079 & .4124 & .140926 \\
\hline \multirow{3}{*}{2016} & Less than 1000 billion VND & ROE & 32 & -1.5464 & 1.0118 & .033048 \\
\hline & 1000 billion - 5000 billion VND & ROE & 15 & -.0484 & .1978 & .074360 \\
\hline & Over 5000 billion VND & ROE & 4 & .0307 & .3087 & .145997 \\
\hline
\end{tabular}

Source: Compiled by the authors based on research results

The lowest ROE of $-181.76 \%$ is in 2014 , means the owner had to bear a loss of 18.176 VND for every 1 VND invested in 1 year, while the highest ROE is $6133 \%$, and these highest and lowest ROE all come from companies less than 1000 billion VND. In 2015 and 2016, there were a number of companies operating loss with earnings before interest and taxes below 0 , resulting in loss for the owner. In 2015, the highest level of ROE was $6.509 \%$. The construction market was still attractive to investors. Assessing the relationship between the capital structure and ROA of listed construction companies is accomplished by analyzing the correlation matrix to find out the relationship between independent variables and dependent variables in the model. Before analyzing the factors affecting ROA, Skewness was applied to examine the distribution of the data set, and the result showed that the data set was not normally distributed due to the secondary data set. For this reason, Spearman's Rank correlation has been used instead to analyze the relationship between factors affecting ROA. The results show that: P-value of three variables: LERa (total debt/total capital), TANG1 (fixed assets/total asset) and EQ_1 (equity/total capital) are 0.000 which is less than 0.005. Therefore, there is a relationship between these three variables and ROA. Fixed assets to total assets had a positive relationship with ROA as indicated by $\beta$ (Spearman Correlation) $=0,271$. This experiment proves that in a specific period of time, if a construction company invests more in fixed assets, it would end up with higher ROA. This result also confirms the effect of operating leverage, i.e. when a firm passes their breakeven point; investing more in fixed assets would result in higher EBIT and vice versa. On the other hand, $\beta$ of LERa and EQ_1 are -0.54 and 0.53 , respectively, meaning that total debt/total assets had a negative relationship with ROA. Therefore, if a firm relies more on debts to finance their assets would be in the downturn stage of the economy, ROA would decrease and vice versa. Thus, finance independence would help to improve ROA. Multi-variables regression analysis, estimate parameters and test the hypothesis of the model were conducted on the data set of 59 construction companies listed on the Stock Exchange in Vietnam in a three-year period (2014-2016) by using SPSS22. This analysis helps to assess whether there is any variable affected by another variable in the same model; and if there is a relationship like that, whether it is a positive or negative correlation. Multi-variables regression is used to examine the soundness of the hypothesis about independent variables in model 01 . OLS is used to estimate the parameters and T-test is applied to verify the supposition for the model with the confidence interval of $95 \%$.

$\mathrm{H}_{0}$ : there is a positive relationship between $\mathrm{Xi}$ and $\mathrm{ROA}$

$\mathrm{H}_{1}$ : there is no positive relationship between $\mathrm{Xi}$ and $\mathrm{ROA}$

The result of multi-variables regression analysis is presented in the Table 3 as follows:

Table 3

Explanation parameters of the model

\begin{tabular}{lllll}
\hline \multicolumn{2}{l}{ Model Summary } & & & \\
\hline Model & R & R Square_R $\mathbf{R}^{\mathbf{2}}$ & Adjusted R Square & Std. Error of the Estimate \\
\hline 1 & $.993^{\mathrm{a}}$ & .986 & .986 & .2299010 \\
2 & $.993^{\mathrm{b}}$ & .987 & .987 & .2206084 \\
3 & $.994^{\mathrm{c}}$ & .988 & .987 & .2159114 \\
\hline
\end{tabular}

a. Predictors: (Constant), TANG1_Fixed assets/Total assets

b. Predictors: (Constant), TANG1_Fixed assets/Total assets, LERb_Long-term debt/Total capital

c. Predictors: (Constant), TANG1_Fixed assets/Total assets, LERb_Long-term debt/Total capital, LERa_Total debt/Total capital

Source: Compiled by the authors based on research results 
Correlation coefficient R of 0.993 in the model (1) shows the close relationship between fixed assets/total assets and ROA. $\mathrm{R}^{2}$ of 0.986 indicates that fixed assets/total assets can explain for $98.6 \%$ the change of ROA. After adding LERa_total debt/total capital and LERb_long-term debt/total capital (model 3), adjudged $\mathrm{R}^{2}$ is 0.987 . This means that when three variables are added into the model, it can explain for $98.7 \%$ the change of ROA $(0.001 \%$ increase compared with the model (1)). In other words, $98.7 \%$ the change of ROA can be explained by independent variables.

Table 4

Result of multivariable regression - ANOVA

\begin{tabular}{|c|c|c|c|c|c|c|}
\hline \multicolumn{2}{|c|}{ Model } & \multirow{2}{*}{$\begin{array}{l}\text { Sum of Squares } \\
586.023\end{array}$} & \multirow{2}{*}{$\begin{array}{l}\text { df } \\
1\end{array}$} & \multirow{2}{*}{$\begin{array}{l}\text { Mean Square } \\
586.023\end{array}$} & \multirow{2}{*}{$\begin{array}{l}\mathbf{F} \\
11087.478\end{array}$} & \multirow{2}{*}{$\frac{\text { Sig. }}{.000^{\mathrm{b}}}$} \\
\hline 1 & Regression & & & & & \\
\hline & Residual & 8.510 & 161 & .053 & & \\
\hline & Total & 594.532 & 162 & & & \\
\hline \multirow[t]{3}{*}{2} & Regression & 586.746 & 2 & 293.373 & 6028.037 & $.000^{\mathrm{c}}$ \\
\hline & Residual & 7.787 & 160 & .049 & & \\
\hline & Total & 594.532 & 162 & & & \\
\hline \multirow[t]{3}{*}{3} & Regression & 587.120 & 3 & 195.707 & 4198.120 & $.000^{\mathrm{d}}$ \\
\hline & Residual & 7.412 & 159 & .047 & & \\
\hline & Total & 594.532 & 162 & & & \\
\hline
\end{tabular}

a. Dependent Variable: ROA

b. Predictors: (Constant), TANG1_Fixed assets/Total assets

c. Predictors: (Constant), TANG1 Fixed assets/Total assets, LERb Long-term debt/Total capital

d. Predictors: (Constant), TANG1_Fixed assets/Total assets, LERb_Long-term debt/Total capital, LERa_Total debt/Total capital

Source: Compiled by the authors based on research results

P-value $<0.05$, means that these three models are appropriate, therefore regression analysis can be applied. However, model (3) is the most appropriate. Multivariable regression applied on independent variables in the model (1) results in P-value $<0.05$, meaning that the estimation of parameters while running regression, therefore the result is statistical significance. This means that there is a relationship between fixed assets/total capital and capital structure, indicated through: long-term debt/total capital, total debt/total capital, total debt/total capital.

Table 5

Result of multivariable regression

\begin{tabular}{|c|c|c|c|c|c|c|c|}
\hline \multirow[t]{2}{*}{ Model } & \multicolumn{2}{|c|}{ Unstandardized Coefficients } & \multirow{2}{*}{$\begin{array}{l}\text { Standardized } \\
\text { Coefficients } \\
\text { Beta } \\
\end{array}$} & \multirow[t]{2}{*}{$-\mathbf{t}$} & \multirow[t]{2}{*}{ Sig. } & \multicolumn{2}{|c|}{ Collinearity Statistics } \\
\hline & $\overline{\mathbf{B}}$ & Std. Error & & & & Tolerance & VIF \\
\hline $\begin{array}{ll}1 & \text { (Constant) }\end{array}$ & -.147 & .044 & & -3.357 & .001 & & \\
\hline LERb_Long-term debt/Total capital & -.331 & .095 & -.032 & -3.489 & .001 & .965 & 1.037 \\
\hline Number of years in operation & .002 & .003 & .006 & .689 & .492 & .969 & 1.032 \\
\hline LERa_Total debt/Total capital & -.034 & .013 & -.023 & -2.521 & .003 & .919 & 1.088 \\
\hline LERc_Total debt/Equity & $1.915 \mathrm{E}-5$ & .000 & .003 & .388 & .698 & .993 & 1.007 \\
\hline TANG1_Fixed assets/Total assets & 1.243 & .011 & .993 & 111.455 & .000 & .997 & 1.004 \\
\hline EQ 1_Equity/total capital & .043 & .049 & .008 & .884 & .378 & .916 & 1.092 \\
\hline
\end{tabular}

a. Dependent Variable: ROA

Source: Compiled by the authors based on research results

The equation for regression can be rewritten as follows:

$$
R O A=-0,147+0,993 \times T A N G 1-0,023 \times L E R a-0,032 \times L E R b+e_{i}
$$

If any variable increases or decreases one unit while other variables are fixed, ROA changes on average as below:

- An increase (or decrease) of $1 \%$ of fixed assets/total assets results in an increase (or decrease) of 0.993 of ROA.

- An increase (or decrease) of $1 \%$ of total debt/total capital results in a decrease (or increase) of 0,023 of ROA.

- An increase (or decrease) of $1 \%$ of Long-term debt/total capital results in a decrease (or increase) of 0,032 of ROA.

To assess the relationship between capital structure and ROE, we have conducted correlation matrix in order to examine the relationship between the dependent variables and independent variables in ROE model. Similar to the ROA regression model (model 1), because data are often not distributed, to analyze the relationship between factors and ROE, the Spearman's Rank correlation is used instead (Trong \& Chu, 2015). The results have shown that the P value of the three variables ROA, TANG1fixed assets / total assets and total liabilities/equity equals $0.000(<0.005)$, which means that these three variables are related to ROE. The result is shown that P-value of three variables ROA, TANG1- fixed assets/total assets and total debt/equity are equal to $0.000(<0.005)$, which suggests that these three variables have a relationship with ROE. $\beta$ (Spearman Correlation) of 0.237 also suggests that fixed assets/total assets have a relationship with ROE. The higher the level of fixed assets/total assets is, the higher the ROE is. Experiment analysis conducted in this research is not against the meaning of the degree of total leverage 
T.T.T. Vu et al. /Accounting 6 (2020)

which shows the relationship between the level of fixed assets and ROE in a firm. $\beta$ of ROA and total debt/equity are 0.553 and -0.233 , respectively, suggesting the positive relationship between ROA and ROE, and a negative relationship between total debt/equity and ROE. Multivariable regression analysis for ROE, estimation of parameters of the model and test the hypothesis of the model for ROE is conducted similar to ROA. Multivariable regression analysis is applied in order to verify the supposition about the relationship between independent variables of the model 02 and ROE. The result is shown in Table 6 as follows:

Table 6

Explanation coefficients of the model

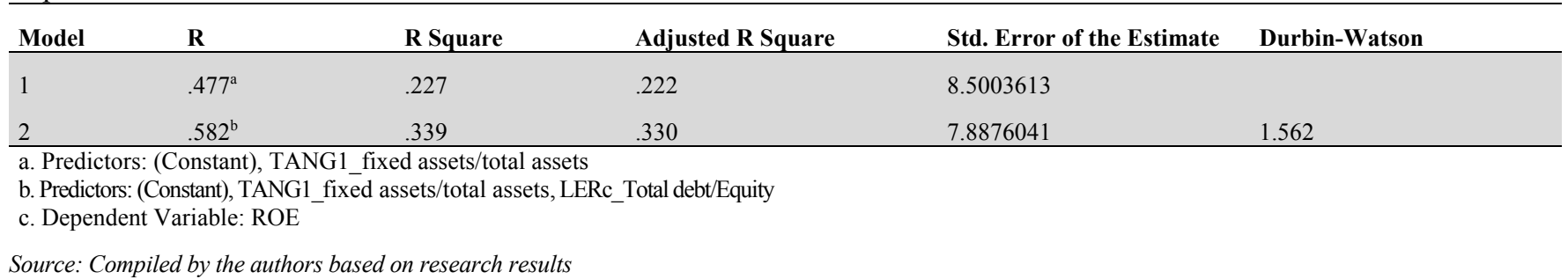

The result in Table 6 shows that $\mathrm{R}^{2}$ in the model (2) is $33 \%$, which suggests that there is $33 \%$ out of $100 \%$ the change of ROE is from independent variables, other from other factors, not in the model. Also, the results of ANOVA test are presented in Table 7 as follows,

Table 7

Result of multivariable regression - ANOVA

\begin{tabular}{lllll}
\hline \multicolumn{1}{l}{ ANOVA } & & & \\
\hline \multicolumn{1}{l}{ Model } & Sum of Squares & df & Mean Square \\
\hline 1 & Regression & 3438.891 & 1 & 3438.891 \\
& Residual & 11705.495 & 162 & 72.256 \\
& Total & 15144.386 & 163 & \\
\hline 2 & Regression & 5127.884 & 2 & 2563.942 \\
& Residual & 10016.502 & 161 & 62.214 \\
& Total & 15144.386 & 163 & \\
\hline
\end{tabular}

a. Dependent Variable: ROE _ Return on equity

b. Predictors: (Constant), TANG1_fixed assets/total assets

c. Predictors: (Constant), TANG1_fixed assets/total assets, LERc_total debt/equity

Source: Compiled by the authors based on research results

Significance level of F-statistics for 2 models with P-value $<0.5$ suggests that capital structure has relationship with ROE. Therefore, three models are appropriate for regression analysis.

Table 8

Result of multivariable regression

\begin{tabular}{|c|c|c|c|c|c|c|c|c|}
\hline \multirow{2}{*}{\multicolumn{2}{|c|}{ Model }} & \multicolumn{2}{|c|}{$\begin{array}{l}\text { Unstandardized } \\
\text { Coefficients }\end{array}$} & \multirow{3}{*}{$\begin{array}{c}\begin{array}{c}\text { Standardized } \\
\text { Coefficients }\end{array} \\
\text { Beta } \\
\end{array}$} & \multirow[t]{2}{*}{$\mathbf{t}$} & \multirow[t]{2}{*}{ Sig. } & \multicolumn{2}{|c|}{ Collinearity Statistics } \\
\hline & & B & Std. Error & & & & Tolerance & VIF \\
\hline \multirow[t]{2}{*}{1} & (Constant) & .638 & .674 & & .947 & .345 & & \\
\hline & TANG1_fixed assets/total assets & 3.011 & .436 & .477 & 6.899 & .000 & 1.000 & 1.000 \\
\hline \multirow[t]{3}{*}{2} & (Constant) & .458 & .626 & & .731 & .466 & & \\
\hline & TANG1 fixed assets/total assets & 3.030 & .405 & .480 & 7.481 & .000 & 1.000 & 1.000 \\
\hline & LERc_total debt/equity & .009 & .002 & .334 & 5.210 & .000 & 1.000 & 1.000 \\
\hline
\end{tabular}

The result of multivariable regression analysis with dependent variables listed in the model (2) shows that the estimation of parameters while applying regression is statistically significant since $\mathrm{P}$-value $<0.05$. This means that there is a relationship between fixed assets/total assets and capital structure, shown by two variables: TANG1_ fixed assets/total assets and total debt/equity. Tolerance in the test is more than 0.17 and VIF less than 10 suggesting that there is no correlation between variables affecting beta parameter estimation. The equation for regression can be rewritten as follows:

$$
\mathrm{ROE}=0.458+0.48 \times \mathrm{TANG} 1+0.334 \times \text { LERc }+\mathrm{e}_{\mathrm{i}}
$$

If one variable increases or decrease one unit while other variables are fixed, ROE changes on average as follows:

- An increase (or decrease) of $1 \%$ of fixed assets/total assets results in an increase (or decrease) of 0.48 of ROE.

- An increase (or decrease) of $1 \%$ of total debt/total capital results in a decrease (or increase) of 0,334 of ROE. 


\section{Conclusion}

In summary, first, based on data set from 2014-2016, we have found no evidence for the relationship between the number of years in operation, total assets, long-term debt/total capital, total debt/total capital and ROA, ROE, although several other studies have found out this relationship. Secondly, the results have shown that there was a relationship between other factors and ROA, ROE and these factors can explain for $96.8 \%$ the change of ROA and 33\% the change of ROE in listed construction companies on Stock Exchange in Vietnam. Third, regression result suggests the strongest positive relationship between fixed assets/total assets and ROA, ROE among factors taken into this research, which reveals the need of increasing the effectiveness of fixed assets in construction companies. Fourth, debt/equity has maintained a positive relationship with ROE, suggesting that the higher the level of debt/equity is, the higher the ROE is. Fifth, debt/total capital and long-term debt/total capital maintained a negative relationship with ROA and they both had similar effects on ROA, which implies that in the recession of the economy, with the slow speed of development of the market, high level of debt could have negative effect on the profitability of total assets However, in order to figure out if there are differences in the level of capital when examining the relationship between LERc and ROE, and to find out the persuasive basis for solutions, correlation analysis between LERc (debt/equity) and ROE is conducted by level of capital and by year.

\section{References}

Chaganti, R., \& Damanpour, F. (1991). Institutional ownership, capital structure, and firm performance. Strategic management journal, 12(7), 479-491.

David, D. F., \& Olorunfemi, S. (2010) 'Capital Structure and Corporate Performance in Nigeria Petroleum Industry : Panel Data Analysis' Journal of Mathematics and Statistics, 6(2), 168 - 173.

Dawar, V. (2014). Agency theory, capital structure and firm performance: some Indian evidence. Managerial Finance, 40(12), $1190-1206$.

Hasan, M. B., Ahsan, A. F. M. M., Rahaman, M. A., \& Alam, M. N. (2014). Influence of capital structure on firm performance: Evidence from Bangladesh. International Journal of Business and Management, 9(5), 184 - 194.

Lan, T.T.P. (2013). Contruction and real estate companies, risks from the financial leverage. VNU Journal of Science, Economics and Business, 29(3), 68 - 74.

Margaritis, D., \& Psillaki, M. (2010). Capital structure, equity ownership and firm performance. Journal of Banking and Finance, 34(3), 621 - 632.

$\mathrm{Su}, \mathrm{G} . \mathrm{S} .$, \& Vo, H. T. (2010). The relationship between corporate strategy, capital structure and firm performance: An empirical study of the listed companies in Vietnam. International Research Journal of Finance and Economics, 50, 62-71.

Salim, M., \& Yadav, R. (2012). Capital structure and firm performance: Evidence from Malaysian listed companies. ProcediaSocial and Behavioral Sciences, 65, 156-166.

Son, T.H. (2008). Capital structure and firm performance. Banking Technology, 33, 31-35.

Tu, T.T.T. (2006). The renovation of capital structure of state-owned enterprises. PhD thesis, National Economic University, Hanoi, Vietnam.

Trong, H., \& Chu, N. M. N. (2015). Analyzing research data with SPSS. $2^{\text {nd }}$ ed, Hong Duc, Hanoi.

Tudose, M. B. (2012). Capital Structure and Firm Performance. Economy Transdisciplinarity Cognition, $15(2), 76$ - 82.

Xu, W., Xu, X., \& Zhang, S. ( 2005). An empirical study on relationship between corporation performance and capital structure. China - USA Business Review, 4(4), 49 - 53.

Zeitun, R., \& Tian, G. G. (2007). Capital structure and corporate performance : evidence from Jordan. Australasian Accounting Business and Finance Journal, 1(4), 40 - 61.

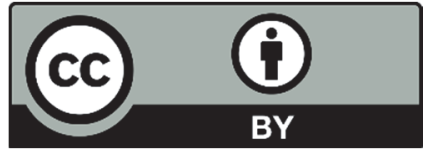

(C) 2019 by the authors; licensee Growing Science, Canada. This is an open access article distributed under the terms and conditions of the Creative Commons Attribution (CC-BY) license (http://creativecommons.org/licenses/by/4.0/). 